\title{
ANALYSIS OF PRACTICAL IMPLEMENTATION OF SOCIAL INNOVATION IN EUROPEAN UNION
}

\author{
Svetlana Polovko', Mg.oec.; Vladimir Shatrevichs ${ }^{2}$, Dr.oec, and \\ Gunta Grinberga-Zalite ${ }^{3}$, Dr.oec. \\ 1,3 3 atvia University of Life Sciences and Technologies, ${ }^{2}$ Riga Technical University
}

\begin{abstract}
EU is promoting social innovation - the European Disability Strategy is part European Pillars of Social Rights. It is estimated that more than $\mathbf{8 0}$ million Europeans with disabilities are in need of special services. People with disabilities experience a lot challenges that arise from socializing, so that they cannot fully enjoy their life's. Innovating or anticipating disability-related social innovations can contribute to product and services for disabled people, but also to eliminate social barrier and to integrate them into society. The aim is to analyse the ways for implementation of social innovation which is bringing maximum value of life for people with disabilities. We expect that factor values affecting people with disabilities may vary since we have different regional infrastructure, social support and services.

This literature review study sheds researches social inclusion among people with disabilities. Results: We investigated main domains and factors representing main values for people with disabilities. Findings from this study indicate that people with disabilities may feel deep depression and anxiety in response to social isolation. This study may contribute to values of perceived isolation and promote social barrier elimination. Conclusion: The social tasks associated with regional disability-oriented infrastructure as support require attention in literature. Offering social innovation and assessing current level of needs in regions to people with disabilities will significantly increase social value.
\end{abstract}

Keywords: social innovation, disability, individual value, regional development, social barriers, social isolation.

JEL code:, L31, M14, O35, Z13

\section{Introduction}

The European Pillar of Social Rights in 20 principles is representing the guideline towards a strong social Europe full of opportunity in the $21^{\text {st }}$ century. The European Disability Strategy is part European Pillars of Social Rights (Principle 17) - Equal opportunity. The latest European Pillar of Social Rights Action Plan is talking mostly about creating jobs, training for adults and poverty as major targets (EU Commission, 2021). People with disabilities have a higher risk of poverty or social exclusion (28.4\%) compared to persons without disabilities (18.4\%) and problems to access jobs and receive proper training - over half of persons with disabilities say they personally felt discriminated against in 2019 (Special Eurobarometer, 2019).

One of six people in the European Union (EU) have a disability and experience many barriers to access the physical environment and to participate in society as equals(Wutz, 2020) and we see it as very topical. This year the European Disability Strategy 2010 - 2020 is coming to an end and The European Commission is currently preparing a post-2020 European Disability Rights Agenda for the next decade(EUD, 2020). The process of evaluation of the current strategy is ongoing and the publication of a new strategy was foreseen in 2021 (EU Comission, 2020). To achieve further progress in ensuring the full participation of persons with disabilities, the new and strengthened Strategy for the Rights of Persons with Disabilities 2021-2030 was accepted in March 2021 (European Union, 2021). The new strategy was launched in 2021, is based on the results of the activities of the European Disability Strategy 2010-2020, one of the priorities of whch was a barrier-free Europe and enabling persons with disabilities to enjoy their rights and fully participate in society.

In our paper we pay attention to people with disabilities in order to investigate factors which help to increase social value and help to create social innovation. Our paper object is social innovation; our aim is to analyse the ways for implementation of social innovation which is bringing maximum value of life for 
people with disabilities. Our hypothesis is that there is possibility improve people's lives by breaking the social distance barrier between people. In order to achieve that we wish to conduct Systematic Literature Review to research factors affecting people quality of life.

\section{Research clusters and focus}

Based on data and analysis of Global Burden of Disease, the number of people with disabilities at the population level associated with health conditions showed a steady growth of $6.3 \%$ over the period 2006-2016 (World Health Organization, 2019). It is projected that between 2015 and 2030, the number of people aged 60 years and over will increase of $23 \%$ and by $32.2 \%$ among people aged 80 years and over, which in turn, will increase the prevalence of disability (UN Department of Economic and Social Affairs Population Division, 2015). Only $9 \%$ of touristic services provide accessible offers. Current market value of accessible travel and tourism is $€ 394$ billion (TRAN Commettee, 2018). It must be recognized that due to attitudinal and/or physical barriers, people whith disabilities are unable to fully participate in society (EU Commission, 2014).

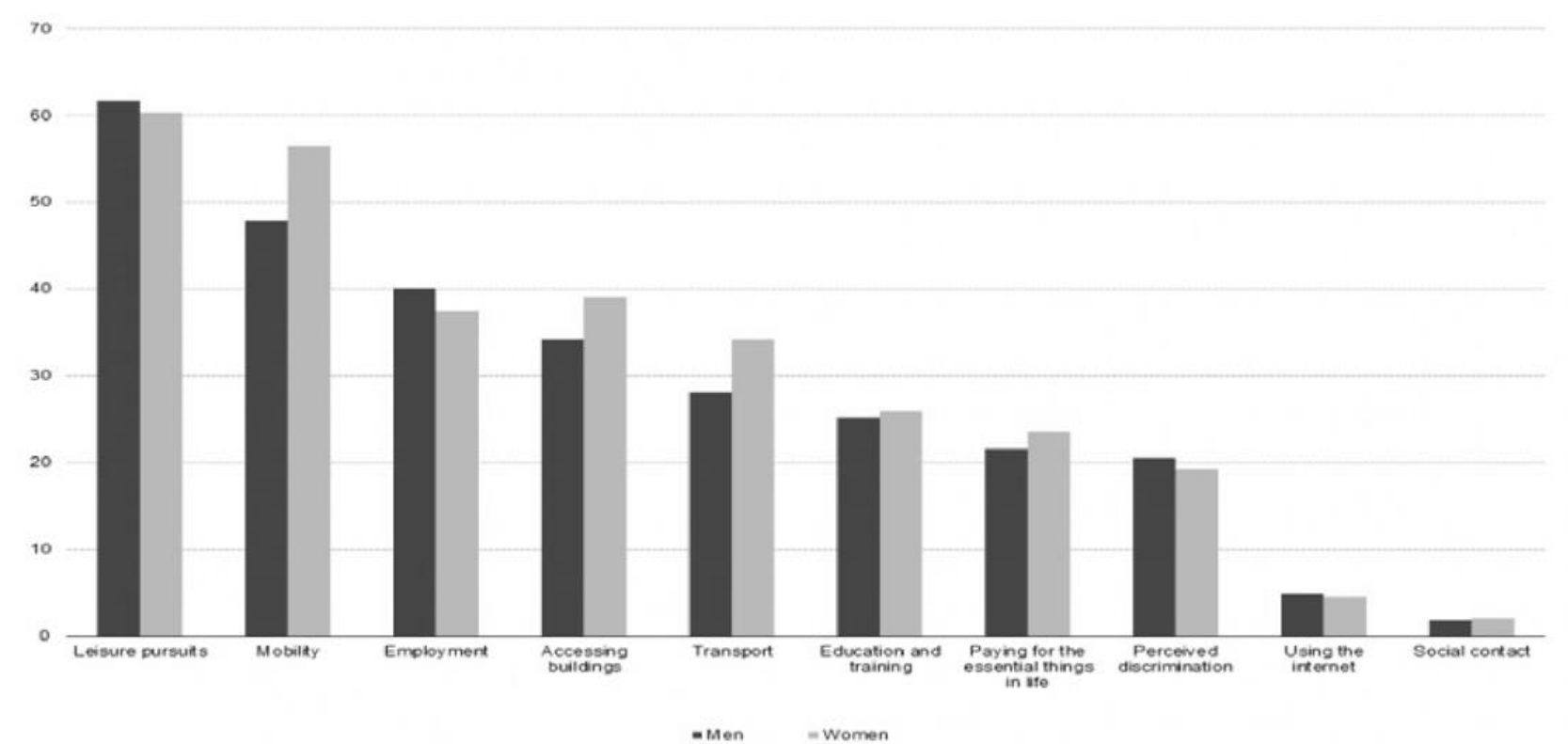

Source: Eurostat (online data code: hlth_dsi090)

Figure 1 . Number of persons with disabilities by sex, 15+ years, whith disability in the specified life areas, EU-27, 2012.

Considering the demand for travel from tourists with disabilities and the elderly, it is revealed that in the EU Member States, this is approximately 780 million trips, and an approximate income of $€ 400$ billion per year. The demand for travel will be growing by $1 \%$ every year. If accessible services for people with disabilities were created, the analysis shows a potential increase in demand per year for accessible tourism and travel by $44 \%$ per year. The value of accessible tourism market could be much higher (44\% more) if there were more accessible offers for people with disabilities on the market. Inaccessible tourism does not allow people with disabilities and/or limited mobility to fully participate in society on equal terms. There are currently a large number of people with disabilities who face travel problems, and this number may increase due to the significant growth of the aging population in the EU. Given these changes, it is very important to develop tourism accessibility in the EU Member States.

According to the 2014 research by Surey University for the European Commision, the problem of lack of accessibility in the EU travel industry threatens to lose up to $€ 142$ billion per year according to inadequate infrastructure, attitudes and services towards travellers with special requirements for access. 
Researchers of Surey University found that people, who are travelling within the EU who require special access conditions (due to age or disability) made 783 million travels in 2012, generating $€ 394$ billion in the EU economy and approximately 8.7 million jobs. Bu it is important to remember that if European destinations were accessible to all visitors with special needs, this demand could grow up to $44 \%$ per year, creating an additional $€ 142$ billion GDP and creating 3.4 million jobs (European Commission, 2015). So we see at as very perspective dimension for social innovation, new jobs, training and digitalization of economy that will considerably increase both social value and economic development (Polovko et al., 2019).

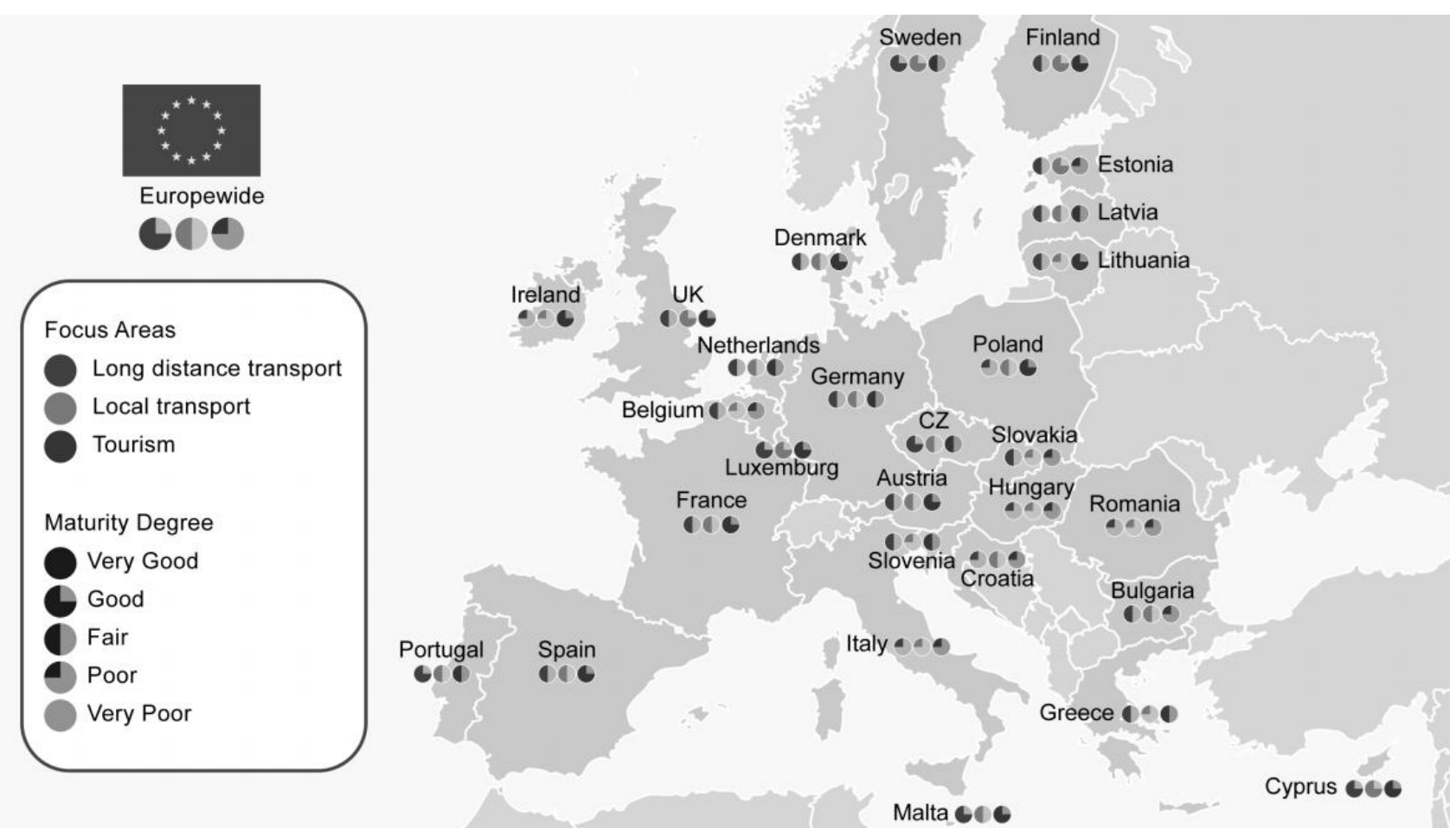

Source: Research for TRAN Committee - Transport and tourism for persons with disabilities and persons with reduced mobility

\section{Figure 2. The accessibility of the local, tourism and long-distance transport} in EU Member State.

The disability-friendly market segment is very fragmented (Figure 2) and does not have any large global players in Baltic States (in contrast to the tourism market that is larger and dominated by a few big players. These players however are not active in disabled segment due to scalability barriers. The research has identified 313286 tourism companies in EU, and 224.036 companies were found in the published data from 79 Accessibility Information Schemes in 24 Eoropean Union Member States. 


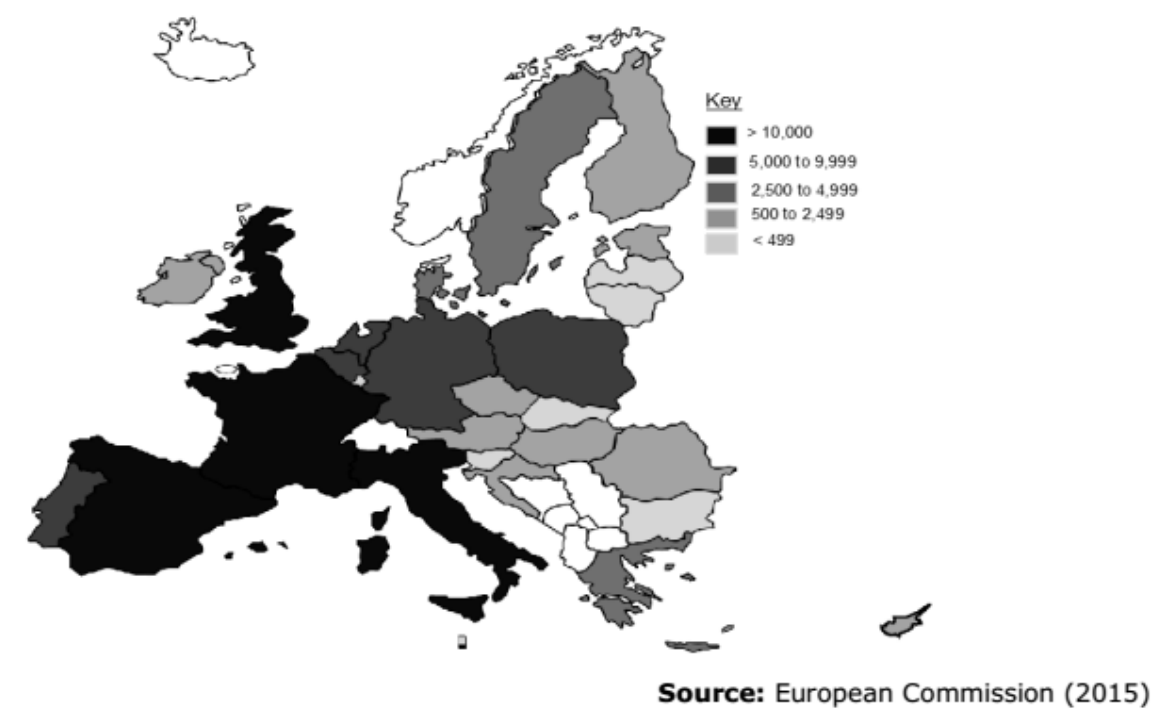

Souce: based AIS and Pantou Sources. (220/PP/ENT/PPA/12/6491) Final Report, 02 April 2015.

Figure 3. Map of the number of Accessible Tourism Suppliers in EU-28

However, a number of caveats can be noted in this study, mainly due to the fact that they can only be considered as the "declared" providers of affordable tourism service in these two datasets. The number of avaliabletourism service providers in EU will recently be an unknown number, especially given that there is no official registration of such companies and the services they offer in the EU. In addition, there are undeniably many methods for defining and measuring "accessibility", what means that nomenclature and metric issues should optimally be reduced to more manageable concepts in order to reveal useful statistics. Finally, vendors can improve infrastructure availability conditions that are not registered or publicised, but can improve access for different customer groups. The map below shows the frequency of avaliable travel service providers in the EU Member States in 5 ranges from below 499 to over 10.000 (Figure 2)

Market competition in services can be divided by approach, process and used technology into four segments (Figure 4):

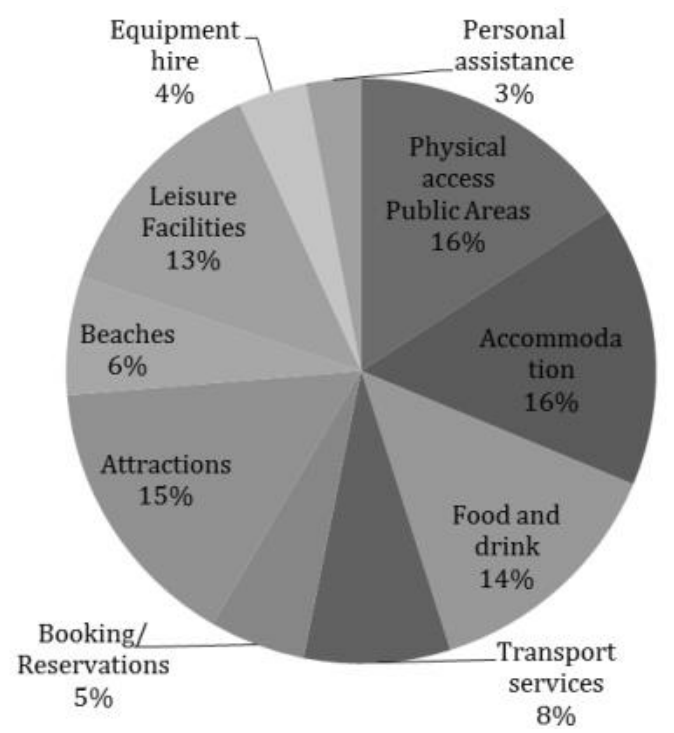

Source: Mapping and Performance Check of the Supply of Accessible Tourism Services (220/PP/ENT/PPA/12/6491) Final Report, 02 April 2015.

Figure 4. Frequency of Accessible Services Information in 79 National and Regional AIS (\%) 
The Pantou (EU leading web-platform in Disability Transport \& Tourism sector and users) the analysis identified over 146,760 avaliable services more than 94.551 providers in the EU-28. All servicces include serving different groups of clients. The main types of services are accommodation, wellness and conference facilities, and the main customers are people with mobility impairments (including wheelchair users), people who are deaf or have hearing impairments and people who are blind or have vision impairments. Based on the above data, it is assumed that about $9.2 \%$ of the current offer of tourist facilities and services available, a partial level of provision for travellers with special needs. This data is based on the mapping carried out in the study compared to the total supply of tourism businesses. This means that more than 3 million travel businesses are not ready to provide services for people with disabilities. By 2021, an additional 1.2 million companies should provide accessible services in order to accommodate the lowest forecasted demand (European Commission, 2014).

So we concentrated on 4 areas as factor groups of public value for end-users:

- accessible transportation both local and long distance,

- accessible tourism and leisure,

- centers providing socialization both digital and physical,

- work opportunities and training.

\section{Research results and discussion}

In order to narrow search for crucial factors about values for disability the bibliometric analysis of publications was done. Information search for bibliometric analysis was performed using the Scopus. Basic search parameters were defined as such: search by name, period from 2000 Until 2021, type of documents analyzed- "article". 


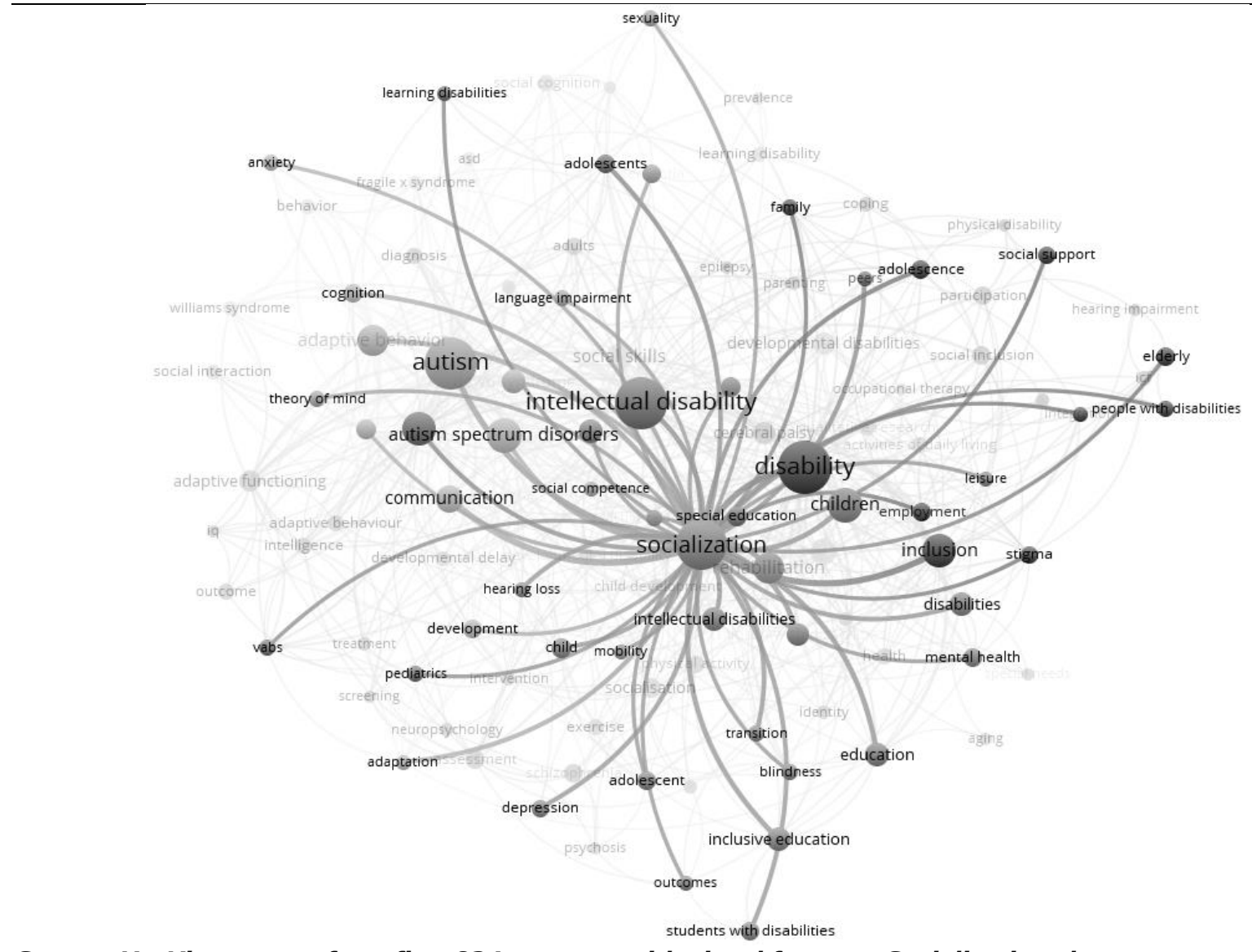

Source: VosViewer map from first 834 sources, with visual focus on Socialization cluster

Figure 5. Frequency of author keyword co-occurance from Scopus

A search of the Scopus database by name was performed using keywords corresponding to the English name of the green organization and their synonyms: green organisation, green organization, green company, green business, green management, green enterprenership (search summary: TITLE: ("disability" OR "green organization" OR "socialization") AND DOCUMENT TYPES: (Article). Timespan: 2000-2021, last decade. Information processing and visualization for bibliometric analysis were prepared using VOSviewer. Search results: 834 articles in English, which contain the keywords mentioned above Figure 5.

As wee see, the most topical keywords are related to factor groups of public value for end-users (Accessible transportation both local and long distance, accessible tourism and leisure, centers providing socialization both digital and physical, work opportunities and training): eployment, communication, leisure, social support and competence, mobility etc. Also we see the focus on social barriers: adaptation, inclusiveness, depression, cognition, anxiety, stigma, social inclusion, psychosis. By selecting 40 most relevant papers we found most crucial factors affecting people with disabilities. According to limitations of references of this paper, authors offer to see concentrated version of analysis in Table 1. 
Factors affecting people with disabilities

\begin{tabular}{|c|c|c|c|}
\hline $\begin{array}{c}\text { Accessible } \\
\text { transportation both } \\
\text { local and long } \\
\text { distance }\end{array}$ & $\begin{array}{l}\text { Accessible tourism } \\
\text { and leisure }\end{array}$ & $\begin{array}{c}\text { Socialization both digital } \\
\text { and physical }\end{array}$ & $\begin{array}{c}\text { Work opportunities } \\
\text { and training } \\
\text { (education) }\end{array}$ \\
\hline $\begin{array}{l}\text { Public } \\
\text { transportation } \\
\text { mobility (Zalewska, } \\
\text { Migliore and } \\
\text { Butterworth, 2016; Hu } \\
\text { and Schneider, 2017; } \\
\text { Grisé et al., 2019; } \\
\text { Henly and Brucker, } \\
\text { 2019) }\end{array}$ & $\begin{array}{c}\text { Accessible social } \\
\text { and economic } \\
\text { services (Lin et al., } \\
\text { 2012; Mackett and } \\
\text { Thoreau, } \\
\text { 2015)(Arbour- } \\
\text { Nicitopoulos and } \\
\text { Ginis, 2011) }\end{array}$ & $\begin{array}{l}\text { Community participation/ } \\
\text { Disability awareness } \\
\text { (Sundar et al., 2016; Fisher } \\
\text { and Purcal, 2017; Toro- } \\
\text { Hernandez et al., 2020) }\end{array}$ & $\begin{array}{l}\text { Employment } \\
\text { possibilities } \\
\text { (Brucker, 2015; Wo } \\
\text { et al., 2015; Lorenti } \\
\text { et al., 2020) }\end{array}$ \\
\hline \multirow[t]{2}{*}{$\begin{array}{l}\text { Regional } \\
\text { infrastructure } \\
\text { barriers (Lockwood, } \\
\text { 2004; Noland and } \\
\text { Thomas, 2007; Frank } \\
\text { et al., 2008) }\end{array}$} & $\begin{array}{c}\text { Leisure needs/ } \\
\text { Loneliness (Sweet, } \\
\text { Ginis and } \\
\text { Tomasone, 2013; } \\
\text { Pels and Kleinert, } \\
\text { 2016; Bonnell et al., } \\
\text { 2021) }\end{array}$ & $\begin{array}{c}\text { Social isolation/ Stigma } \\
\text { /Exclusion/ } \\
\text { Connectedness (Chen et al., } \\
\text { 2012; Cacioppo and } \\
\text { Cacioppo, 2014; Cochran, } \\
\text { 2020; Repke and Ipsen, } \\
\text { 2020) }\end{array}$ & $\begin{array}{c}\text { Education and } \\
\text { training } \\
\text { (G.Grinberga-Zalite } \\
\text { et al., 2019; Bose } \\
\text { and Heymann, 2020; } \\
\text { Stillman et al., 2020; } \\
\text { Spencer, Riley and } \\
\text { Young, 2021) }\end{array}$ \\
\hline & $\begin{array}{c}\text { Health and } \\
\text { wellness centers } \\
\text { (Kissow, 2015; } \\
\text { Mulligan, Miyahara } \\
\text { and Nichols- } \\
\text { Dunsmuir, 2017; } \\
\text { Calder, Sole and } \\
\text { Mulligan, 2018) }\end{array}$ & $\begin{array}{c}\text { Digital socialization } \\
\text { (Domingo, 2012; Myers et } \\
\text { al., 2017; Abel, Machin and } \\
\text { Brownlow, 2019; Peterson- } \\
\text { Besse, Knoll and Horner- } \\
\text { Johnson, 2019; Kadijevich, } \\
\text { Masliković and Tomić, 2020; } \\
\text { Epstein et al., 2021; Martinsa } \\
\text { et al., 2021; van Holstein et } \\
\text { al., 2021) }\end{array}$ & \\
\hline
\end{tabular}

Source: authors's group synthesis based on scientifical papers (concentrated version)

At the moment, the expertise to accessibility tourism services is rare in Baltic States (Age-friendly tourism is more common). This is due to a very time-consuming service and know-how demanding specific to each patient. Another critical problem of current state of the art - socialization barriers. For children with disabilities, making friends and forming relationships can be especially challenging. Social obstacles are very difficult to overcome (we also call it attitudinal barriers). Attitudinal barriers that lead to stigmatisation and discrimination, can deprive people with disabilities of their development and dignity, and are also the biggest obstacle to achieving equality of opportunity and social inclusion. A negative attitude towards people creates an unfavorable environment in all spheres of life. They are quite often expressed in the the inability of people with disabilities to see their violation; fear; bullying; discrimination; and lowered expectations of people with disabilities.

\section{Conclusions, proposals, recommendations}

1) Overall, $15 \%$ of the world population (1 billion people) lives with some forms of disability, and it is expected to affect more than 1.2 billion people by 2021 . Over $20 \%$ of the global population will be over 65 by 2050 . Concerning the EU, one in six people has a disability (from mild to severe), translating into approximately 80 million citizens. Only $9 \%$ of European Union travelling companies offered services provide accessible offers. Current market value of accessible travel and tourism is $€ 394$ billion. Very 
often, due to physical and/or attitudinal barriers, these people are excluded from participating fully in society and in the economy.

2) The most topical keywords are related to factor groups of public value for end-users are: eployment, communication, leisure, social support and competence, mobility etc. Also we see the focus on social barriers: adaptation, inclusiveness, depression, cognition, anxiety, stigma, social inclusion, psychosis.

3) Our solution is to assess current refional differences regarding disability-friendly support in order to promore social innovation. The next part of our research is to conduct survey based on developed factors. The investigation of regional needs will significantly contribute to the EU strategy for disabled people in terms the effectiveness and improve the socialization, increase the accessibility of disabled people tourism across EU

4) The impact of Disability projects does not appear to have been systematically examined, although they may each have helped the development of Accessible Tourism and Transport within their respective geographical areas. Having committed resources at European level to enterprises there might have been a follow-up study to extract lessons learned and identify strategies for social innovation in EU Member States to help them develop social inclusion of people with disabilities across a wider front. Inaccessible society can prevent people with disabilities and/or reduced mobility from participating in society on equal terms. At present there are significant numbers of people with disabilities who face social barriers and this number is likely to increase in the near future with the significant growth of the ageing population in the EU. Given these changes, it is essential that social innovation related to Accessible Society in EU Member States should be developed.

\section{Bibliography}

1. Abel, S., Machin, T. and Brownlow, C. (2019) 'Support, Socialise and Advocate: An Exploration of the Stated Purposes of Facebook Autism Groups', Research in Autism Spectrum Disorders, 61, pp. 10-21. DOI: 10.1016/j.rasd.2019.01.009.

2. Arbour-Nicitopoulos, K. P. and Ginis, K. A. M. (2011) 'Universal Accessibility of "Accessible" Fitness and Recreational Facilities for Persons With Mobility Disabilities', Adapted Physical Activity Quarterly, 28(1), pp. 115. DOI: 10.1123/apaq.28.1.1.

3. Bonnell, K. et al. (2021) 'Physical Activity for Individuals Living with a Physical Disability in Quebec: Issues and Opportunities of Access', Disability and Health Journal. DOI: 10.1016/j.dhjo.2021.101089.

4. Bose, B. and Heymann, J. (2020) 'Do Inclusive Education Laws Improve Primary Schooling Among Children With Disabilities?', International Journal of Educational Development, 77. DOI: 10.1016/j.ijedudev.2020.102208.

5. Brucker, D. L. (2015) 'Social Capital, Employment and Labor Force Participation Among Persons With Disabilities', Journal of Vocational Rehabilitation, 43(1), pp. 17-31. DOI: 10.3233/JVR-150751.

6. Cacioppo, J. T. and Cacioppo, S. (2014) 'Social Relationships and Health: The Toxic Effects of Perceived Social Isolation', Social and Personality Psychology Compass, 8(2), pp. 58-72. DOI: 10.1111/spc3.12087.

7. Calder, A., Sole, G. and Mulligan, H. (2018) 'The Accessibility of Fitness Centers for People With Disabilities: A systematic review', Disability and Health Journal, 11(4), pp. 525-536. DOI: 10.1016/j.dhjo.2018.04.002.

8. Chen, C. H. et al. (2012) 'The Image of People With Intellectual Disability in Taiwan Newspapers', Journal of Intellectual and Developmental Disability, 37(1), pp. 35-41. DOI: 10.3109/13668250.2011.650159.

9. Cochran, A. L. (2020) 'Understanding the Role of Transportation-related Social Interaction in Travel Behavior and Health: A qualitative study of adults with disabilities', Journal of Transport and Health, 19. DOI: $10.1016 /$ j.jth.2020.100948.

10. Domingo, M. C. (2012) 'An Overview of the Internet of Things for People With Disabilities', Journal of Network and Computer Applications, 35(2), pp. 584-596. DOI: 10.1016/j.jnca.2011.10.015.

11. Epstein, S. et al. (2021) 'New Obstacles and Widening Gaps: A Qualitative Study of the Effects of the COVID-19 Pandemic on U.S. Adults with Disabilities', Disability and Health Journal. DOI: https://doi.org/10.1016/j.dhjo.2021.101103.

12. EU Comission (2020) A Strong Social Europe for Just Transitions. Retrieved: https://ec.europa.eu/commission/presscorner/api/files/document/print/en/qanda_20_20/QANDA_20_20_EN.pd f.. Access: 15.01 .2021

13. EU Commission (2014) Mapping Skills and Training Needs to Improve Accessibility in Tourism Services. 204/PP/ENT/PPA/12/6471. 
14. EU Commission (2021) 'The European Pillar of Social Rights Action Plan'. Retrieved: https://ec.europa.eu/info/strategy/priorities-2019-2024/economy-works-people/jobs-growth-and-invest ment/european-pillar-social-rights/european-pillar-social-rights-action-plan_en. Access: 17.01.2021

15. EUD (2020) European Disability Rights Agenda 2020 - 2030.

16. European Commission (2014) Economic Impact and Travel Patterns of Accessible Tourism in Europe. Service Contract SI2.ACPROCE052481700.

17. European Commission (2015) Mapping and Performance Check of the Supply of Accessible Tourism Services. 220/PP/ENT/PPA/12/6491.

18. European Union (2021) Union of EqualityStrategy for the Rights of Persons with Disabilities 2021-2030. DOI: $10.2767 / 31633$.

19. Fisher, K. R. and Purcal, C. (2017) 'Policies to Change Attitudes to People with Disabilities', Scandinavian Journal of Disability Research, 19(2), pp. 161-174. DOI: 10.1080/15017419.2016.1222303.

20. Frank, L. et al. (2008) 'Urban Form, Travel Time, and Cost Relationships with Tour Complexity and Mode Choice', Transportation, 35(1), pp. 37-54. DOI: 10.1007/s11116-007-9136-6.

21. Grinberga-Zalite, G., Rivza, B., Zvirbule, A., Tihankova, T. (2019) - Promoting Digital Skills in Higher Education to Strengthen the Competitiveness of the EU Human Capital. 19th International multidisciplinary scientific GeoConference SGEM 2019 : conference proceedings, Albena, Bulgaria, 30 June-6 July, 2019 / Bulgarian Academy of Sciences - Sofia, 2019. - Vol. 19, Issue 5.4. Ecology, economics, education and legislation. Section: Education and accreditation in geosciences. Environmental legislation, multilateral relations and funding opportunities, p. 259-266. - ISBN 9786197408874 - ISSN 1314-2704

22. Grisé, E. et al. (2019) 'Elevating Access: Comparing Accessibility to Jobs by Public Transport for Individuals With and Without a Physical Disability', Transportation Research Part A: Policy and Practice, 125, pp. 280-293. DOI: $10.1016 /$ j.tra.2018.02.017.

23. Henly, M. and Brucker, D. L. (2019) 'Transportation Patterns Demonstrate Inequalities in Community Participation for Working-age Americans with Disabilities', Transportation Research Part A: Policy and Practice, 130, pp. 93-106. DOI: 10.1016/j.tra.2019.09.042.

24. van Holstein, E. et al. (2021) 'People With Intellectual Disability and the Digitization of Services', Geoforum, 119, pp. 133-142. DOI: 10.1016/j.geoforum.2020.12.022.

25. Hu, L. and Schneider, R. J. (2017) 'Different Ways to Get to the Same Workplace: How does Workplace Location Relate to Commuting by Different Income Groups?', Transport Policy, 59, pp. 106-115. DOI: 10.1016/j.tranpol.2017.07.009.

26. Kadijevich, D. M., Masliković, D. and Tomić, B. M. (2020) 'Dataset Regarding Access to Information for Persons with Disabilities in Serbia', Data in Brief, 32. DOI: 10.1016/j.dib.2020.106309.

27. Kissow, A. M. (2015) 'Participation in Physical Activity and the Everyday Life of People with Physical Disabilities: a Review of the Literature', Scandinavian Journal of Disability Research, 17(2), pp. 144-166. DOI: 10.1080/15017419.2013.787369.

28. Lin, S. F. et al. (2012) 'Trends in US Older Adult Disability: Exploring Age, Period, and Cohort Effects', American Journal of Public Health, 102(11), pp. 2157-2163. DOI: 10.2105/AJPH.2011.300602.

29. Lockwood, S. (2004) Transportation in Rural America: Challenges and Opportunities. Minneapolis, MN. Retrieved: www.cts.umn.edu/sites/default/files/files/events/oberstar/2004/2004 lockwood paper.pdf. Access: 27.01.2021

30. Lorenti, A. et al. (2020) 'Working and Disability Expectancies at Older Ages: The Role of Childhood Circumstances and Education', Social Science Research, 91. DOI: 10.1016/j.ssresearch.2020.102447.

31. Mackett, R. L. and Thoreau, R. (2015) 'Transport, Social Exclusion and Health', Journal of Transport and Health, 2(4), pp. 610-617. DOI: 10.1016/j.jth.2015.07.006.

32. Martinsa, A. P. et al. (2021) '"amik@" Social Media Platform for People with Intellectual Disability', Procedia Computer Science, 181, pp. 716-721.

33. Mulligan, H., Miyahara, M. and Nichols-Dunsmuir, A. (2017) 'Multiple Perspectives on Accessibility to Physical Activity for People with Long-term Mobility Impairment', Scandinavian Journal of Disability Research, 19(4), pp. 295-306. DOI: 10.1080/15017419.2016.1167772.

34. Myers, L. et al. (2017) 'Socialization Characteristics in Persons with Epilepsy', Epilepsy and Behavior, 72, pp. 99-107. DOI: 10.1016/j.yebeh.2017.04.036.

35. Noland, R. B. and Thomas, J. V. (2007) 'Multivariate Analysis of Trip-chaining Behavior', Environment and Planning B: Planning and Design, 34(6), pp. 953-970. DOI: 10.1068/b32120.

36. Pels, F. and Kleinert, J. (2016) 'Loneliness and Physical activity: A Systematic Review', International Review of Sport and Exercise Psychology, 9(1), pp. 231-260. DOI: 10.1080/1750984X.2016.1177849.

37. Peterson-Besse, J. J., Knoll, J. E. and Horner-Johnson, W. (2019) 'Internet Networks as a Source of Social Support for Women with Mobility Disabilities During Pregnancy', Disability and Health Journal, 12(4), pp. 722726. DOI: $10.1016 /$ j.dhjo.2019.04.003.

38. Polovko, S., \& Grinberga-Zalite, G. (2019). Legal Framework of Social Innovation: Case Study of Latvia. International Multidisciplinary Scientific GeoConference Surveying Geology and Mining Ecology Management, SGEM, , 19(5.3) 483-490. DOI:10.5593/sgem2019/5.3/S21.061

39. Repke, M. A. and Ipsen, C. (2020) 'Differences in Social Connectedness and Perceived Isolation Among Rural and Urban Adults with Disabilities', Disability and Health Journal, 13(1). DOI: 10.1016/j.dhjo.2019.100829. 
40. Special Eurobarometer (2019) Discrimination in the EU. 493. Retrieved: https://ec.europa.eu/commfrontoffice/publicopinion/index.cfm/ResultDoc/download/DocumentKy/88272. Access: 27.01.2021

41. Spencer, S. A., Riley, A. C. and Young, S. R. (2021) 'Experiential Education Accommodations for Students with Disabilities in United States Pharmacy Schools: An exploratory study', Currents in Pharmacy Teaching and Learning. DOI: $10.1016 /$ j.cptl.2021.01.044.

42. Stillman, M. D. et al. (2020) 'A Survey of Internal and Family Medicine Residents: Assessment of Disabilityspecific Education and Knowledge', Disability and Health Journal. DOI: 10.1016/j.dhjo.2020.101011.

43. Sundar, V. et al. (2016) 'Community and Social Participation Among Adults with Mobility Impairments: A Mixed Methods Study', Disability and Health Journal, 9(4), pp. 682-691. DOI: 10.1016/j.dhjo.2016.05.006.

44. Sweet, S. N., Ginis, K. A. M. and Tomasone, J. R. (2013) 'Investigating Intermediary Variables in the Physical Activity and Quality of Life Relationship in Persons with Spinal Cord Injury', Health Psychology, 32(8), pp. 877885. Retrieved: http://www.embase.com/ search/results?subaction=viewrecord\&from=export\&id=L370283413\%0Ahttp://dx.doi.org/10.1037/a0032383. Access: 27.01.2021

45. Toro-Hernandez, M. L. et al. (2020) 'Factors that Influence the use of Community Assets by People with Physical Disabilities: Results of Participatory Mapping in Envigado, Colombia', BMC Public Health, 20(1). DOI: 10.1186/s12889-020-8285-9.

46. TRAN Commettee (2018) 'Transport and Tourism for Persons with Disabilities and Persons with Reduced Mobility'. Retrieved: https://www.europarl.europa.eu/RegData/etudes/STUD/2018/617465 /IPOL_STU(2018)617465_EN.pdf. Access: 27.01.2021

47. United Nations Department of Economic and Social Affairs Population Division (2015) World population ageing.

48. Wo, M. C. M. et al. (2015) 'Employability in People with Epilepsy: A Systematic Review', Epilepsy Research, 116, pp. 67-78. DOI: 10.1016/j.eplepsyres.2015.06.016.

49. World Health Organization (2019) World Report on Disability. Available at: https://www.euro.who.int/_data/assets/pdf_file/0016/420163/Disability-SDG-factsheet.pdf.

50. Wutz, I. (2020) The European Parliament Sets Priorities for the EU Disability Strategy post-2020, COFACE. Retrieved: http://www.coface-eu.org/disability/the-european-parliament-sets-priorities-for-the-eu-disabilitystrategy-post-2020/. Access: 18.01.2021

51. Zalewska, A., Migliore, A. and Butterworth, J. (2016) 'Self-determination, Social skills, Job Search, and Transportation: Is there a Relationship with Employment of Young Adults with Autism?', Journal of Vocational Rehabilitation, 45(3), pp. 225-239. DOI: 10.3233/JVR-160825. 